\title{
Fulani in Ghana: Emerging Mission Possibilities and Approaches
}

Haruna Yussif Mogtari ${ }^{1}$

${ }^{1}$ Step Missions International (SMI) Nalerigu, North East Region, Ghana.

\begin{abstract}
The Fulani in Ghana for decades have largely remained unengaged in mission work. The factors that have hindered any meaningful engagement by the Church among this widely spread people group in West Africa are several and include the perennial farmer-herder conflicts, prejudice, stereotype, and fear of the Fulani among indigenous people. These factors have for a long time made it appear impossible for the Church to become a witness among the Fulani in Ghana. This research first, explores the few mission attempts made by some mission agencies. To evangelise the Fulani, the research work secondly examines the challenges associated with Christian mission among the Fulani and the difficulties faced by the Fulani in their daily lives with their cattle. Thirdly, the paper investigates emerging mission possibilities and approaches among the Fulani as a nomadic group. The framework that allows one to explore these possibilities holistically are the Five Marks of Global Mission as outlined in Mission in 21 ${ }^{\text {st }}$ Century; Exploring the Five Marks of Global Mission. Lastly, the research highlights the importance of contextualization in mission, especially that the Fulani must essentially hear, understand, and respond to the Gospel in their native language, Fulfulde.
\end{abstract}

Keywords: Stigmatized Fulani, Conflict, Five Marks of Global Missions

\author{
Correspondence: \\ Haruna Yussif Mogtari \\ Email: harunamogtari@gmail. \\ com \\ Manuscript \\ Received 5th June 2020, \\ Accepted 11th August 2020, \\ Published online 17th August \\ 2020.
}

\section{INTRODUCTION}

In Ghana, there has not been a people so discriminated against because of their ethnicity than the Fulani. Yet, embedded in this culturally diverse group are sparks of truth and beauty worth studying. The paradoxical nature of the Fulani is the motivation for this article. At one point they appear antagonistic, and on another side, they are perceived to be positive by those who work closely with them on a mission. The Fulani are the most widely spread ethnic group in the whole of West Africa. They are officially referred to as the Fulbe or Pullo ${ }^{2}$ and speak Fulfulde as their mother tongue. They are also referred to, as fellata or Peul ${ }^{3}$ in other contexts.

The origin of the Fulani has remained a 'mystery' for most Africans for decades because they are highly mobile for generations. It was not until the middle of the $20^{\text {th }}$ Century that reliable documents were discovered which proved that the Fulani are indigenous to Africa, Senegambia region, to be precise. ${ }^{4}$ They arrived in the northern parts of Ghana around 1911 and since then their numbers have soared, and in the 2000 Population and Housing Census, they had reached $300,000 .^{5}$

Conflicts involving a few of the Fulani herdsmen and local farmers have been the major news items on some media platforms for decades casting negative perceptions on the Fulani community and the resulting consequences are

\footnotetext{
Singular of Fulbe

3 H.R. Palmer \& H.H Johnston, “'The Fulas” and their Language’ Journal of the Royal African Society, Vol. 22, No. 86 (1923), pp. 121, 128, Accessed 15 January 2015, http://www.jstor.org/stable/715991.

4 Derrick J. Stenning, Savannah Nomads; A Study of the Wodaabe Pastoral Fulani of Western Bornu Province Northern Region, Nigeria (Munster; Hamburg: Lit, 1994), p. 20.

5 Steve Tonah, Fulani in Ghana: Migration History, Integration and Resistance (Legon-Accra: The Research and Publication Unit, Department of Sociology, University of Ghana, 2005), pp. 2-3.
} 
bigotry, ethnic labelling, stigma, and ostracism. More to this, there is a general Fulanimophobia among a large section of Ghanaians because of their pastoral activities. For these reasons, the Church appears to have shied away from the Fulani and for years they have been out of reach with the gospel. Therefore, this article explores the emerging mission possibilities and approaches to Christian mission with the Fulani in focus, as a contribution to the global mission in the Ghanaian context. Studies in the Mission in 21 ${ }^{\text {st }}$ Century; Exploring the Five Marks of Global Mission reveal five key areas with which contemporary mission must not compromise. ${ }^{6}$ The importance of these five marks cannot be overemphasized, as this paper is hinged on them.

\section{What are the Five Marks of Contemporary Global Mission?}

Mission, as exemplified by Jesus in Scripture, has been rediscovered with fresh understanding, expanded scope, and clearly explained, in the Five Marks of Global Mission by the contributors of the above book. In brief, these marks cover five significant elements and these are as follows:

1. 'To Proclaim the Good News of the Kingdom (i)" ${ }^{\text {? }}$ and 'To Proclaim the Good News of the Kingdom (ii)'; 8

2. 'To Teach, Baptise, and Nurture New Believers (i) ${ }^{9}$ and 'To Teach, Baptise, and Nurture New Believers(ii)'; $;{ }^{10}$

3. 'To Respond to Human Need by loving Service (i)' ${ }^{11}$ and 'To Respond to Human Need by loving Service(ii)'; $;$ '

4. 'To Seek to Transform Unjust Structures of Society (i)' ${ }^{13}$ and 'To Seek to Transform Unjust Structures of Society (ii) ${ }^{\prime} ;{ }^{14}$

5. 'To Strive to Safeguard the Integrity of Creation and Sustain and Renew the Life of the Earth (i) ${ }^{15}$ and 'To Strive to Safeguard the Integrity of Creation and Sustain and Renew the Life of the Earth (ii). ${ }^{16}$

These Five marks address mission in different contexts that call for interfaith approach, the proclamation of the Word, discipleship, contextualizing theological curricula, care for creation, compassionate Christian service, and theological reflection on structural injustice. Subsequently, this article shall engage these marks with a Christian mission to the Fulani.

\section{Social and Economic Difficulties of Fulani, and challenges in Christian mission}

The root cause of the discrimination, marginalization, and suffering of the Fulani is the long-standing perception that they are foreigners and for that reason, they have no right within the jurisdiction of Ghana. Scuffles between Fulani herdsmen and farmers remain the headlines in the Ghanaian media space since the 1990's causing much rage among citizens. ${ }^{17}$ In dealing with these farmer-herder conflict, what often happens is that Ghanaians choose to remain oblivious to the situation. So, the nation has not been able to get to the crux of the matter to resolve these conflicts. One truth stands out, the majority of the cattle that are cared for by many Fulani households are for Ghanaian farmers, the privileged, and the ruling class. However, poor Fulani families become the object of attacks and castigation. Many Fulani who are not even herdsmen become victims of ethnic victimization in the hands of the media, the state, and local people. Still, the hard truth that Ghanaians must face is that there are significant numbers of the Fulani in Ghana who are citizens.

\footnotetext{
${ }_{6}$ Andrew F. Walls \& Cathy Ross (eds.), Mission in the 21 $1^{\text {st }}$ Century; Exploring the Five Marks of Global Mission (Maryknoll, New York: Orbis Books, 2008).

7 Ken Gnanakan, 'To Proclaim the Good News of the Kingdom (i)', in Mission in the 21 ${ }^{\text {st }}$ Century; Exploring the Five Marks of Global Mission, eds. Andrew Walls and Cathy Ross (Maryknoll, New York: Orbis Books, 2008),. 3-10.

8 D. Zac Niringiye, 'To Proclaim the Good News of the Kingdom (ii)', in Mission in the 21 $1^{\text {st }}$ Century; Exploring the Five Marks of Global Mission, eds. Andrew Walls \& Cathy Ross (Maryknoll, New York: Orbis Books, 2008),. 11-24.

9 Emmanuel Egbunu, 'To Teach, Baptise, and Nurture New Believers (i)', in Mission in the 21 $1^{\text {st }}$ Century; Exploring the Five Marks of Global Mission, eds. Andrew Walls \& Cathy Ross (Maryknoll, New York: Orbis Books, 2008),. 25-36.

10 Ande Titre, 'To Teach, Baptise, and Nurture New Believers (ii)', in Mission in the 21 $1^{\text {st }}$ Century; Exploring the Five Marks of Global Mission, eds. Andrew Walls \& Cathy Ross (Maryknoll, New York: Orbis Books, 2008), 37-45.

11 Melba Maggay, 'To Respond to Human Need by Loving Service (i)', in Mission in the 21 $1^{\text {st }}$ Century; Exploring the Five Marks of Global Mission, eds. Andrew Walls \& Cathy Ross (Maryknoll, New York: Orbis Books, 2008), 46-52.

12 Haami Chapman, 'To Respond to Human Need by Loving Service(ii)', in Mission in the 21 ${ }^{\text {st }}$ Century; Exploring the Five Marks of Global $\backslash$ Mission, eds. Andrew Walls \& Cathy Ross (Maryknoll, New York: Orbis Books, 2008), 53-61.

13 Valdir Raul Steuernagel, 'To seek to Transform Unjust Structures of Society (i)', in Mission in the 21 $1^{\text {st }}$ Century; Exploring the Five Marks of Global Mission, eds. Andrew Walls \& Ross (Maryknoll, New York: Orbis Books, 2008), 62-76.

14 Bev Haddad, 'To seek to Transform Unjust Structures of Society (ii)', in Mission in the 21 $1^{\text {st }}$ Century; Exploring the Five Marks of Global Mission, eds. Andrew Walls \& Cathy Ross (Maryknoll, New York: Orbis Books, 2008), 77-83.

15 Calvin B. DeWitt, 'To Strive to Safeguard the Integrity of Creation and Sustain and Renew the Life of the Earth (i)', in Mission in the 21 ${ }^{\text {st }}$ Century; Exploring the Five Marks of Global Mission, eds. Andrew Walls \& Cathy Ross (Maryknoll, New York: Orbis Books, 2008 ), 84-93.

16 Dave Bookless, 'To Strive to Safeguard the Integrity of Creation and Sustain and Renew the Life of the Earth (ii), in Mission in the 21 ${ }^{\text {st }}$ Century; Exploring the Five Marks of Global Mission, eds. Andrew Walls \& Ross (Maryknoll, New York: Orbis Books, 2008), 94-104.

17 Tonah, Fulani in Ghana, 3-4.
} 
The Citizenship Act, 2000 (Acts 591), section 1-7 of Ghana's Constitution, affirm descendants of early Fulani migrants (before and after 1957) who either by birth or naturalization and registration have since made Ghana their home. However, the majority of them maintain that they are foreign nationals. ${ }^{18}$

As a result of the stigmatization of being a Fulani, preconceptions, and hatred, many poor Fulani households would want to keep out of trouble by isolating themselves and are thereby denied access to social and economic amenities in their host communities. This accounts to some extent, for the lack of education and inaccessibility to healthcare and other socio-economic opportunities. However, some households that have good relations with their indigenous neighbours often get the opportunity to use their facilities.

The stigma faced by that ordinary Fulani among their neighbours and their seclusion from people considered foreign to them are obstacles which require conscious attention and response by Christian missionaries. If the Fulani are acknowledged as full members of the societies in which they live and those in Christian mission work with them to face life's challenges, then there are great possibilities for the opening up of the Fulani community to Christ in the long term. The warmth and neighbourliness that Christ teaches Christians especially through the story of the Good Samaritan in Luke 10:33-36 inform Christian mission about the significance of relationship and love to suffering and stigmatized people such as the Fulani, as reflected in Jesus' statement:

But a Samaritan, who was on a journey, came upon him; and when he saw him, he felt compassion, and came to him and bandaged up his wounds, pouring oil and wine on them; and he put him on his own beast, and brought him to an inn and took care of him. ${ }^{19}$

Responding to the health needs and other necessities of life is paramount to uplifting the dignity of the Fulani. As Christian workers, engage the Fulani community in mission holistically, in a manner that addresses their felt needs, this may eventually provide opportunities for witness and discipleship. Mission organizations need to study the annual and periodic migration patterns of nomads to inform them on how to design a missionary approach that considers the mobile nature of the Fulani in general. For instance, one possibility may be to institute Christ-centred education and health programs that suit Fulani migratory nature. It is important to consider how these educational programmes are funded and what incentives there are to attract their attention and seriousness.

In the third mark of mission, 'To respond to human need by loving service', Melba Maggay ${ }^{20}$ and Haami Chapman ${ }^{21}$ help us to understand the essence of the Christian duty of caring for the needy and the vulnerable in society. According to Maggay 'To follow God is to love him with passion, and, similarly, to love our neighbour with the same care and total attention that we shower on ourselves. ${ }^{22}$ She implies that the love for God is demonstrated in a physical expression of love and care for others, 'those who are swept to the margins and are rendered vulnerable because of scarce resources, outright lack of means for survival, or not having the right ethnicity or nationality. ${ }^{23}$ In the course of this research, this was a statement a Pullo made about their quest for someone to 'release' them from their unbearable condition:

It is how God can help us or use someone to come and help us so that we can live taking care of people's cattle- a tedious and unprofitable work so we can be a part of society and become human beings. ${ }^{24}$

This statement is very revealing; this author perceives it as a strong call for a holistic and integrated mission among the Fulani. Serving the Fulani with loving and compassionate care will not only help to meet the needs of the Fulani but also become an entry point for Christian mission among the Fulani who are deprived socially, economically, and politically.

Generally in Ghana, the Fulani have been unjustly treated due to the misconception, prejudgment and the stereotypes many Ghanaians hold about them and their occupation, even though sometimes the misbehavior of some of the Fulani may account for this. It is pertinent that missionaries who work among Fulani take interest in their problems because the mission of the Church is holistic and thus should be involved in transforming these social injustices through the peace and love of God that it claims.

In the fourth mark of mission, Valdir Raul Steuernagel affirms the integration of the 'five marks of mission. ${ }^{25} \mathrm{He}$ emphasizes that 'we affirm justice as a fundamental expression of God's search for transformation, as a mark of mission

\footnotetext{
18 Haruna Y. Mogtari, 'Fulani Herdsmen Traditions and Care for the Land' in Essays on the Land, Ecotheology, and Traditions in Africa, eds. Benjamin Abotchie Ntreh, Mark S. Aidoo, \& Daniel Nii Aboagye Aryeh (Eugene: Wipf and Stock Publishers, 2019), 178-191.

19 Luke 10:33-36 (NIV)

20 Chapman, 'To Respond to Human Need by Loving Service', 53-61.

21 Maggay, 'To Respond to Human Need by Loving Service', 46-52.

${ }^{22}$ Ibid.

23 Ibid, 48.

24 Amadu Sambu, Interview, $31^{\text {st }}$ July 2015, Sakpalua.

25 Steuernagel, 'To seek to Transform Unjust Structures of Society', 62-76.
} 
and the need to integrate it into our portfolio of mission. ${ }^{26} \mathrm{He}$ also demonstrates from the Scriptures that Jesus' ministry was holistic and that the Gospel denounces enslavement to idolatry, oppression, and injustice, and also identifies with the poor and the suffering by bringing liberation, wholeness, and peace to them. From Steuernagel's argument, therefore, it is clear that the mission to the Fulani cannot ignore the need to correct injustice in their communities.

Challenges in Fulani ministry seem to be many and therefore the few discussed here may not be exhaustive. It is common for a Pullo to hide behind the curtain and pose as a Muslim against any attempt of being evangelized even though he may not be a practicing Muslim. Though missionaries can communicate with the Fulani in Ghanaian languages, most of the missionaries cannot speak Fulfulde. Communication and relationships sometimes can hit the rocks especially in an attempt by missionaries to share the gospel for the Fulani to understand. Similarly, it is very difficult for missionaries to develop a deep connection with the Fulani without resort to the mother tongue Fulfulde. George Warrik, a missionary among the Fulani in Niger, recounted that even though he was learning to communicate the gospel in Fulfulde, he regarded it as a difficult language to learn. ${ }^{27}$ This may be so for many other missionaries working among the Fulani outside of their cultural milieu.

\section{Emerging Mission Possibilities and Approaches}

This section is most crucial for mission practitioners. It points them to the heart of fruitful and meaningful engagement in Fulani Christian mission in the context of Ghana and some theological issues that one may have to consider to become successful in this endeavour. Particularly, the fifth mark of mission, 'To strive to safeguard the integrity of creation and sustain and renew the life of the earth' is critical for Christian mission among the Fulani. Calvin B. DeWitt and Dave Bookless point out the relevance of Genesis 1-11; these are God's call to Adam to dress and keep the Garden, and the story of Noah's Ark emphasizing the need to preserve creation. Matthew 28:19-20 and Mark16:15 also provide a theological basis for Christian involvement in an environmental mission if the nations (ethnic groups) are to be spiritually nurtured, that discipleship involves discovering what it means to care for God's creation. In a related article, Kwame Bediako commented especially on the Great Commission, “....Therefore go and make disciples of all nations...”28 that: The Great Commission is not about numbers, nor statistics, important as these are. The Great Commission is not about percentages of national populations that we may consider to have been 'reached' or remain 'unreached' with the Gospel, important as these considerations are...The Great Commission, therefore, is about the discipling of the nations, the conversion of the things that make people into nations- the shared processes of thinking, shared and common attitudes, world views, perspectives, languages, cultural and social and economic habits of thought and behaviour and practice...true evangelization and conversion is turning to Christ all that He finds when He meets us, and asking that He cleanse, purify and sanctify us and all that we are, eliminating what He considers incompatible with Him. That is what the Great Commission is about... ${ }^{29}$

Bediako implies that the emphasis of the Great Commission is not about the number of individuals and people groups or nations that missionaries have been able or unable to evangelize but essentially about discipleship and transformation of the worldviews and all those things that define the nations or ethnic groups of the world. What this means is that every aspect of the Fulani worldview including their environment and identity needs to be transformed by Christ. In Ghana, there have been allegations that the Fulani exploit natural vegetation and water resources. These have contributed to the perennial farmer-herder conflicts which have resulted in both the death of humans and cattle and the destruction of farms. ${ }^{30}$ Thus, the Christian mission among the Fulani cannot avoid responding to this very important aspect of their lives. Here, missionaries have the option and responsibility to help the Fulani to realize God's intention for His creation and how to preserve and renew it.

The Fulani can learn to speak their host language quickly and easily adapt to their culture. This second language of the Fulani is a potential communication entry point for local ministries or any mission that understands the language of their host culture. Missionaries also have the option of engaging with some of them in Hausa or Twi. However, even though the bilingual potential of the Fulani can be appropriated in sharing the Gospel with them and used for discipleship purposes, nevertheless, these second and third languages are no real substitutes for communicating in the Fulfulde language. This is because it is almost impossible for one to engage in any meaningful depth with the Fulani culture using a borrowed language, and for them to feel at home.

The positive utilization of the use of Fulfulde in Christian mission to the Fulani is that missionaries find

\footnotetext{
26 Ibid 64.

27 George Warrik, Interview, 11 September 2015, Fada N'Gourma, Burkina Faso.

28 Matthew 28:18-20 (NIV)

${ }_{29}$ Kwame Bediako, 'What is the Gospel?', Asempa Jubilee Lectures, September 1995 (Manuscript, Akrofi-Christaller Institute, AkropongAkuapem, Ghana), p. 5.

30 George Afolley, 'Fulanis clash with Kwahus: Four Death', Daily Graphic, January 282015.
} 
reception among a rather self-contained society that hardly opens up easily to outsiders. Most especially, through the initial communication of the Gospel in Fulfulde, the missionaries consciously or unconsciously can establish links with their host culture. Allison Howell buttresses this point when she remarks that 'If you want to learn a person's culture and the way he sees his world, you will need to learn his language...because language and culture are inseparable. ${ }^{31}$ Here, it is learned that for the Gospel to appeal to a people's worldview, learning their language and culture is inevitable. For Howell, this orientation shows that missionaries have high regard for the people they want to reach with the Gospel. ${ }^{32}$

On discipleship, Emmanuel Egbunu identifies some core ingredients of discipleship which falls in line with the second mark of mission. Egbunu shows that Christian discipleship is imperative for those who receive the Gospel and also suggests the need for Christian mission to contextualize discipleship to make African new converts feel at home within their traditions. ${ }^{33}$ Among some of the reasons why the clergy and laity are not well resourced for ministry and mission, Ande Titre ${ }^{34}$ suggests, the 'lack of an appropriate theological education. ${ }^{35}$ According to him, 'theological and Bible schools do not have sufficient infrastructure and curricula for contextual training for mission and ministerial formation. ${ }^{36} \mathrm{~A}$ careful study of the Fulani culture shows that there are meanings behind their customs and practices that need scriptural interpretations to align them with God's designed purpose. Therefore, Scripture is crucial to engaging these customs to affirm those that point to Christ and modify the inconsistencies.

The Fulani have great potential, and they are ardent agro-pastoralists. They live very simple lives and can survive on very little. They are very resourceful people and responsible for their families. Fulani pastoralists have wide geographical knowledge of most areas in sub-Saharan Africa and have interacted with different ethnic groups, and for those that come to embrace education, they excel tremendously in school. Missionaries who work with them in Ghana, Niger, Mali, Nigeria, Benin, and Burkina Faso recommend agriculture, health, and education as possible ways through which the Gospel can enter into the Fulani community and be a great blessing to them.

The Fulani have beautiful indigenous stories that easily catch their attention. Learning the form of these stories can be a helpful tool in conveying the Gospel to them. In observing the Fulani, it is obvious that one cannot share the Gospel with them without having a deep interest in them and their preoccupation with cattle. Adding to this, the Fulani are generous people and this opens possibilities for missionaries to give and receive from Fulani as one interacts with them.

From the understanding of the effort of Christian mission among the Fulani in Ghana, as well as the challenges and difficulties, some possible approaches emerge for Christian mission among them. In looking at these approaches, it is important to think through the benefits and difficulties of each. First, one possibility is for mission organizations to consider beginning where other missions have laid the foundation and need reinforcement as well as open new mission fields. This may involve supporting existing missions to revive some of their collapsed Fulani ministries or to begin fresh ministries with the support of these existing ministries. One of the possible difficulties in this approach that could emerge in the future is: if an organisation decides to begin their own independent Fulani ministry with the support of these existing ministries in these areas, there may be a conflict of interest as to where the new converts will be assigned for fellowship. Will it be the existing organization or the supporting ministries? These would be details that would need to be clarified at the outset to avoid conflict.

Second, where Fulani herdsmen live among other ethnic groups that are predominantly Christian, they often seem sympathetic towards Christianity. Some Fulani have testified about how good their 'Christian' cattle owners have been to them and their families; these good relationships have led some Fulani to form good opinions about Christians. In the course of the research, all the Christian workers expressed the opinion that it is easier for a Pullo who herds the cattle of a Christian to become a Christian than a Fulani who herds the cattle of a Muslim. In cases where the cattle owner is a Muslim, the Pullo may fear to convert to Christianity because his Muslim cattle owner would collect his cattle and render him jobless. In a situation like this, the Christian mission would need to reach out to both the Fulani and his cattle owner. One difficulty that can also arise is where a cattle owner who identifies himself as a Christian does not live and practice the Christian life or acts in ways that are contrary to Fulani moral values. Though the cattle owner may be good towards the Fulani, yet his moral life becomes a stumbling block to their salvation and this will not help the missionary's effort in reaching out to the Fulani.

Third, it is clear that there are possibilities for Christian mission to the Fulani in situations where there have been no Christian works among them. The Christian mission would need to identify what is required in terms of first,

\footnotetext{
31 Allison M. Howell, A Daily Guide For Culture and Language Learning, Third Revised Edition (Abokobi, Accra: AmaraZaane Consulting Services Limited, 2014), 8.

32 Ibid., 12.

33 Egbunu, 'To Teach, Baptise, and Nurture New Believers', 25-36.

34 Ande Titre, 'To Teach, Baptise, and Nurture New Believers', 37-45.

35 Ibid 39.

36 Ibid.
} 
capacity building, training of Christian workers, and financial investment. Second, understanding the nature of the area is crucial. If it is a Muslim-dominated area, reception among the Fulani may be very difficult, and mission work may take considerable time to yield fruit. If it is not a Muslim-dominated area, there may still be challenges to face that are related to the attitudes of non-Muslims towards the Fulani, especially if there has been a conflict in that area. In terms of actual details of the approach, from the experiences of missionaries among the Fulani, the evenings are more ideal for accessing them, since they take their cattle for feeding and return at night to their home or camp site. Resources such as the film, the Passion of Christ, and audio Gospel messages in Fulfulde are helpful tools that have contributed to the efforts of missionaries in proclaiming the Gospel among the Fulani in Northern Ghana.

Ken Gnanakan ${ }^{37}$ and D. Zac Niringiye ${ }^{38}$ agree that the core message and task of the Gospel is the proclamation of the kingdom of God in which Jesus, his person, and ministry, is central and also fulfils the Old Covenant. The nature of how the kingdom of God operates is demonstrated in Jesus' mission in Luke 4:17-19 as holistic. According to Gnanakan, the proclamation of the message of Christ need not be provocative especially in Islamic and Hindu contexts. For him 'There is an urgent need for seeing continuities between those to whom we present the Gospel and the Lord Jesus... and...Explore models of proclamation where Christ fits into local cultures. ${ }^{39} \mathrm{He}$ is of the view that Muslims still hold Jesus in high esteem. Missionaries, who work in religiously pluralistic contexts such as Northern Ghana where there is an imposing Muslim presence, need to seriously consider an interfaith approach in their programme by exploring more affinities.

\section{CONCLUSION}

In this paper, some emerging possibilities and approaches that are relevant for the Christian mission to Fulani in Ghana have been noted. These include the creative proclamation of the Gospel in Fulfulde among Fulani households; serving Fulani with loving and compassionate care; responding to injustice related to Fulani and indigenous people; and caring for creation.

Of the key features of the Christian mission that emerged in this paper, language is a crucial aspect that cannot be overlooked. Though the Fulani are a people of many languages and missionaries may decide to share the Gospel with them in a lingua franca depending on the location, yet this is no real substitute for communicating the good news in Fulfulde. Another feature that was noted is that there are cultural and religious peculiarities that missionaries need to comprehend so that they can engage well with them within this cultural and religious milieu. When it comes to Christian mission among the Fulani, it is clear that it requires an interfaith approach in witnessing for Christ, whether the Fulani are devout Muslims, or have a mixture of primal and Islamic beliefs and practices. Within this context, the Christian mission needs to consider approaches that de-stigmatize the Fulani identity. This will require not just a mission to the Fulani but also a Christian mission among the ethnic groups with whom they work. The Christian workers among the Fulani in West Africa are optimistic about the prospects of Fulani mission and ministry in Ghana. However, these prospects will become a reality and many Fulani will accept Jesus as their Lord and Saviour if mission organizations involve these five marks of global mission in their mission praxis.

\section{BIBLIOGRAPHY}

Afolley, George, 'Fulanis clash with Kwahus: Four Death', Daily Graphic, January 282015.

Bediako, Kwame, 'What is the Gospel?', Asempa Jubilee Lectures, September 1995. Manuscript, Akrofi-Christaller Institute, Akropong-Akuapem, Ghana.

Chapman, Haami, 'To Respond to Human Need by Loving Service (ii)', in Mission in the $21^{\text {st }}$ Century; Exploring the Five Marks of Global Mission, edited by Andrew Walls \& Cathy Ross, pp. 53-61. Maryknoll, New York: Orbis Books, 2008.

Dave Bookless, 'To Strive to Safeguard the Integrity of Creation and Sustain and Renew the Life of the Earth (ii), in Mission in the 21 $1^{\text {st }}$ Century; Exploring the Five Marks of Global Mission, edited by Andrew Walls \& Cathy Ross, pp.94-104. Maryknoll, New York: Orbis Books, 2008.

DeWitt, Calvin B., 'To Strive to Safeguard the Integrity of Creation and Sustain and Renew the Life of the Earth (i)', in Mission in the $21^{s t}$ Century; Exploring the Five Marks of Global Mission, edited by. Andrew Walls \& Cathy Ross, pp. 84-93. Maryknoll, New York: Orbis Books, 2008.

Egbunu, Emmanuel, 'To Teach, Baptise, and Nurture New Believers (i)', in Mission in the 21 ${ }^{\text {st }}$ Century; Exploring the Five Marks of Global Mission, edited by Andrew Walls \& Cathy Ross, pp. 25-36. Maryknoll, New York: Orbis

\footnotetext{
37 Gnanakan, 'To Proclaim the Good News of the Kingdom', 3-10.

38 Niringiye, 'To Proclaim the Good News of the Kingdom', 11-24.

39 Gnanakan, 'To Proclaim the Good News of the Kingdom', 3-10.
} 
Books, 2008.

Gnanakan, Ken, 'To Proclaim the Good News of the Kingdom (i)', in Mission in the 21 ${ }^{\text {st }}$ Century; Exploring the Five Marks of Global Mission, edited by Andrew Walls and Cathy Ross, pp. 3-10. Maryknoll, New York: Orbis Books, 2008.

Haddad, Bev, 'To seek to Transform Unjust Structures of Society (ii)', in Mission in the 21 ${ }^{\text {st }}$ Century; Exploring the Five Marks of Global Mission, edited by Andrew Walls \& Cathy Ross, pp. 77-83. Maryknoll, New York: Orbis Books, 2008.

Howell, Allison M., A Daily Guide For Culture and Language Learning, Third Revised Edition. Abokobi, Accra: AmaraZaane Consulting Services Limited, 2014.

Maggay, Melba, 'To Respond to Human Need by Loving Service (i)', in Mission in the $21^{\text {st }}$ Century; Exploring the Five Marks of Global Mission, edited by Andrew Walls \& Cathy Ross, pp. 46-52. Maryknoll, New York: Orbis Books, 2008.

Mogtari, Haruna Y., 'Fulani Herdsmen Traditions and Care for the Land' in Essays on the Land, Ecotheology, and Traditions in Africa, edited by Benjamin Abotchie Ntreh, Mark S. Aidoo, \& Daniel Nii Aboagye Aryeh, pp. 178-191. Eugene: Wipf and Stock Publishers, 2019.

Niringiye, D. Zac, 'To Proclaim the Good News of the Kingdom (ii)', in Mission in the 21 ${ }^{\text {st }}$ Century; Exploring the Five Marks of Global Mission, edited by Andrew Walls \& Cathy Ross, pp. 11-24. Maryknoll, New York: Orbis Books, 2008.

Palmer, H.R. \& H.H Johnston, 'The Fulas' and their Language' Journal of the Royal African Society, Vol. 22, No. 86 (1923), pp. 121, 128, Accessed 15 January 2015, http://www.jstor.org/stable/715991.

Stenning, Derrick J., Savannah Nomads; A Study of the Wodaabe Pastoral Fulani of Western Bornu Province Northern Region, Nigeria. Munster; Hamburg: Lit, 1994.

Steuernagel,Valdir Raul, 'To seek to Transform Unjust Structures of Society (i)', in Mission in the 21 ${ }^{\text {st }}$ Century; Exploring the Five Marks of Global Mission, edited by Andrew Walls \& Ross, pp. 62-76. Maryknoll, New York: Orbis Books, 2008.

Titre, Ande, 'To Teach, Baptise, and Nurture New Believers (ii)', in Mission in the 21 $1^{\text {st }}$ Century; Exploring the Five Marks of Global Mission, edited by Andrew Walls \& Cathy Ross, pp. 37-45. Maryknoll, New York: Orbis Books, 2008.

Tonah, Steve, Fulani in Ghana: Migration History, Integration and Resistance. Legon-Accra: The Research and Publication Unit, Department of Sociology, University of Ghana, 2005.

\section{ABOUT AUTHOR}

Haruna Yussif Mogtari, MA/MTh is a Researcher and Missionary among the Fulani in West Africa. He is the Director of Step Missions International (SMI) in Nalerigu, North East Region of Ghana. He also heads the Centre for Research and Islamic Studies, Ghana. 